\title{
JNPH
}

Volume 7 No. 2 (Oktober 2019)

(C) The Author(s) 2019

\section{PENGARUH SIMULASI MENGHADAPI BENCANA GEMPA BUMI TERHADAP KESIAPSIAGAAN SISWA SDN 86 KOTA BENGKULU}

\author{
THE EFFECT OF SIMULATION IN EARTHQUAKE DISASTERS TO THE \\ STUDENTS 'ALERT PRIVATE VOCATIONAL SCHOOL OF SDN 86 KOTA \\ BENGKULU
}

\author{
NOVA YUSTISIA, TITIN APRILATUTINI, TUTI ANGGRIANI UTAMA \\ PRODI KEPERAWATAN FAKULTAS MATEMATIKA DAN ILMU PENGETAHUAN \\ ALAM UNIVERSITAS BENGKULU \\ Email: nyustisia@unib.ac.id
}

\begin{abstract}
ABSTRAK
Indonesia merupakan daerah rawan bencana gempa bumi dan provinsi Bengkulu adalah salah satu daerah yang mengalami gempa bumi. Gempa yang terjadi pada tahun 2000 menyebabkan banyak korban. Kebanyakan dari mereka adalah orang tua dan anak-anak. Tidak semua anak dilatih untuk menghadapi bencana, oleh karena itu perlu diadakan pelatihan di sekolah dasar sehingga anak-anak memiliki pengetahuan bagaimana menangani bencana ini jika tiba-tiba terjadi. Tujuan utama dari penelitian ini adalah untuk mengetahui pengaruh metode simulasi bencana terhadap kesiapan anak-anak. Desain penelitian menggunakan eksperimen semu dengan dua desain pre post test. Sampel diambil dengan menggunakan sampel tota untuk 62 responden dan data dikumpulkan dengan menggunakan kuesioner. Hipotesis diuji dengan menggunakan U-Man Withney. Hasil: Hasil penelitian ini menunjukkan ada pengaruh terhadap kesiapan bencana metode simulasi anak dengan nilai $\mathrm{P}<0,005$. Kesimpulan: Pelatihan kesiapan menghadapi bencana gempa meningkatkan level kesadaran anak-anak. Semua siswa tingkat 6 SD N 86 Bengkulu mampu dan terlibat setelah pelatihan diulang 5 kali dan sebagian besar anak-anak menunjukkan bahwa tingkat kesadaran dikategorikan sebagai kurang siap.
\end{abstract}

Kata kunci: Pelatihan Kesiapsiagaan Bencana, metode simulasi

\begin{abstract}
Background: Indonesia is located within the ring of fire and Bengkulu is one of the area which is experiencing with earthquake. The earthquake happened in 2000 left many victims. Most of them are elderly and children. Not all children are trained to deal with disaster, therefore it is necessary to conduct a training to elementary school so the children have a knowledge how to deal with this disaster if it is suddenly happened. Objective: The main aims of this research is to find out the effect of disaster simulation method toward the children readiness. Method: The research design applies quasi experiment with two pre post test design. The sample are taken by using tota sample for 62 respondents and the data are collected by using questioners. The hypothesis is tested by using U-Man Withney. Result: The results of this study showed there is influence on the preparedness of disaster simulation method children with a value of $\mathrm{P}<0.005$. Conclusion: The training of readiness to face an earthquake disaster increase the level of
\end{abstract}


children awareness. All of the level 6 SD N 86 Bengkulu elementary students is able and involved after the training was repeated 5 times and most of the children showed that the level of awareness is categorised as less ready

\section{Keywords: Disaster Preparedness Training, simulation method}

\section{PENDAHULUAN}

Permasalahan bencana gempa bumi dan tsunami merupakan masalah besar bagi dunia. Word Disaster Reduction Compaign UNESCO pada tahun 2005 menyatakan bahwa Indonesia merupakan Negara paling sering mengalami bencana dengan urutan ke 7 (Permana H). Menurut data Badan Perencanaan Pembangunan Nasional (BAPPENAS) tahun 2006, sebanyak 208.991 unit rumah rusak ringan sampai berat. Sektor Pendidikan juga tidak luput dari dampak bencana dengan jumlah kerusakan sebanyak 197 sekolah yang hancur dan 765 sekolah dalam kondisi rusak ringan sampai berat (BAPPENAS, 2006).

Kota Bengkulu adalah salah satu bagian dari Provinsi Bengkulu yang rawan bencana. Berdasarkan letak lokasi Kota Bengkulu berada di patahan Sumatera dan subdukasi Lempeng Tektonik Indo_Australia dan lempeng Tektonik Eurasia, Kota Bengkulu juga berada di lereng bukit barisan yang seluruh gunungnya aktif serta memiliki pantai dengan panjang 12 kilo meter. Gempa yang terjadi pada tahun 2000, 2007, menjadi pusat perhatian dunia karena banyaknya kerusakan gedung-gedung, perkantoran, rumah-rumah penduduk, sekolah-sekolah bahkan kecacatan dan kematian pada anak-anak sampai usia lanjut .

Kesiapsiagaan merupakan faktor penting yang menjadi fokus perhatian dewasa ini mengingat kesiapsiagaan adalah faktor penentu untuk pengurangan resiko bencana yang dapat dilakukan dan diupayakan sejak dini (LIPI-UNESCO, 2006). Pengalaman yang ada membuktikan bahwa kurangnya pengetahuan yang dimiliki, rendahnya sikap untuk melakukan antisipasi resiko terjadinya bencana, perilaku negatif untuk pencegahan bencana serta kurangnya kesiapsiagaan dalam menghadapi suatu kondisi bencana memicu untuk terjadinya peningkatan resiko saat bencana terjadi (Bakornas, 2007).

Edukasi mengenai resiko kejadian bencana seharusnya diberikan kepada masyarakat sejak dini. Anak usia sekolah merupakan salah satu change agent yang dapat menjadi prioritas untuk dilakukan pendidikan mengenai resiko bencana. Anak yang berada di sekolah harus siap dan siaga untuk menghadapi kondisi bencana untuk dapat meminimalkan resiko yang dapat terjadi (Chairummi, 2013). Anak-anak merupakan salah satu kelompok rentan yang paling berisiko terkena dampak bencana (PP No 21, 2008). Kerentanan anak-anak terhadap bencana dipicu oleh faktor keterbatasan pemahaman tentang risiko-risiko di sekeliling mereka, yang berakibat tidak adanya kesiapsiagaan dalam menghadapi bencana.

Berdasarkan data kejadian bencana di beberapa daerah banyak korban terjadi pada anak usia sekolah baik di jam sekolah atapun di luar jam sekolah, hal ini menunjukkan bahwa pentingnya pengetahuan tentang bencana dan pengurangan risiko bencana diberikan sejak dini untuk memberikan pemahaman dan pengarahan langkah-langkah yang harus dilakukan saat terjadi suatu ancaman yang ada di sekitarnya untuk mengurangi risiko bencana (Sunarto, 2012). Hasil pengumpulan data awal yang dilakukan pada siswa di SDN 86 Kota Bengkulu sebagian besar siswa tidak mengetahui mengenai tindakan yang harus dilakukan jika bencana gempa datang. Selama ini yang dilakukan siswa saat bencana gempa hanya berlari mengikuti orang tua dan saat di sekolah para siswa mengatakan jika terjadi gempa maka mereka segera lari untuk pulang dan tidak memperhatikan kondisi yang ada disekitar mereka.

Sebagai upaya untuk meningkatkan 
kesiapsiagaan masyarakat dalam pengurangan risiko bencana, lembaga penanggulangan bencana dalam hal ini adalah Palang Merah Indonesia (PMI) Provinsi Bengkulu, Badan Penanggulangan Bencana Daerah (BPBD) Kota Bengkulu harus mampu untuk berkoordinasi dan saling bekerjasama. Berdasarkan hasil observasi di SDN 86 kota Bengkulu yang terletak di pesisir pantai Bengkulu didapatkan bahwa siswa belum pernah mendapatkan simulasi bencana, berdasarkan wawancara terhadap 5 orang siswa, mereka mengatakan bahwa belum tahu cara menyelamatkan diri saat gempa terjadi. Hasil wawancara dengan 2 orang guru didapatkan data sekolah meraka merupakan salah satu sekolah yang rentan mengalami kerusakan gedung pada gempa bumi tahun 2007, belum menjadi sekolah siaga bencana, belum adanya jalur evakuasi, tidak ada peringatan tanda bahaya seperti sirine dan belum adanya pelatihan dan simulasi siaga bencana di sekolah. Berdasarkan latar belakang diatas, maka peneliti tertarik untuk meneliti pengaruh simulasi menghadapi bencana gempa bumi terhadap kesiapsiagaan Siswa SDN 86 Kota Bengkulu.

Tujuan penelitian ini adalah mengetahui pengaruh simulasi menghadapi bencana gempa bumi terhadap kesiapsiagaan sekolah siswa di SDN 86 Kota Bengkulu.

\section{METODE PENELITIAN}

Rancangan penelitian ini menggunakan metode penelitian experiment dengan desain (Quasi eksperimen design) dengan non eguivalent kontrol group design. Dalam penelitian ini peneliti menguji pengaruh simulasi penanggulangan bencana gempa bumi terhadap kesiapsiagaan siswa dalam menghadapi bencana gempa bumi pada siswa SDN 86 Kota Bengkulu. Penelitian ini dilakukan terhadap siswa kelas IV dan V yang berjumlah 31 orang yang diberikan simulasi (kelompok eksperimen) dan 31 orang yang tidak diberikan simulasi (kelompok kontrol). Penelitian ini dilaksanakan selama 1 minggu mulai bulan Juli sampai dengan September
2019. Dalam penelitian ini responden kelompok eksperimen akan mendapatkan pelatihan penanggulangan bencana gempa bumi sebanyak 1 kali pertemuan dengan waktu 120 menit. Pelatihan dilakukan pada hari yang akan disepakati yang meliputi pemberian materi, diskusi, praktek dan simulasi penanggulangan bencana. Untuk pengumpulan data, peneliti memberikan kuesioner berupa sejumlah pertanyaan tentang kesiapsiagaan siswa dalam menghadapi bencana gempa bumi sebelum (pre-test) maupun sesudah (post-test) pelatihan penanggulangan bencana. Waktu yang dialokasikan untuk pengisian kuesioner yaitu selama 15-20 menit. Pre-test dilakukan sebelum responden menerima simulasi sedangkan post-test diberikan 1 minggu setelahnya pada kelompok eksperimen dan kelompok kontrol. Alat ukur yang digunakan dalam pelatihan ini berupa materi power point presentation, LCD proyektor dan sound system. Sebagai alat bantu peneliti juga menyiapkan leaflet materi untuk diberikan kepada siswa peserta pelatihan. Analisis data dari hasil penelitian ini menggunakan program komputer IBM SPSS statistic 24 dengan uji statistik non parametrik two independent sample untuk mengetahui pengaruh antara tingkat kesiapsiagaan siswa sebelum dan sesudah diberikan pelatihan penanggulangan bencana. Dan untuk mengetahui perbedaan kesipasiagaan siswa kelas VII antara yang diberikan intervensi dan tidak diberi intervensi maka digunakan rumus U - Mann Whitney.

\section{HASIL PENELITIAN}

Penelitian ini dilakukan pada bulan Juli sampai dengan Agustus 2019 di SDN 86 Kota Bengkulu.

Tabel 1 Distribusi frekuensi Pre Test Simulasi Penanggulangan Bencana Gempa Bumi Terhadap Kesiapsiagaan Siswa SDN 86 Kota Bengkulu. 


\begin{tabular}{ccc}
\hline $\begin{array}{c}\text { Kategori } \\
\text { Kesiapan }\end{array}$ & Frekuensi & Persentase \\
\hline Belum Siap & 5 & 8,1 \\
\hline Kurang Siap & 5 & 8,1 \\
\hline Hampir Siap & 6 & 9,7 \\
\hline Siap & 6 & 9,7 \\
\hline Sangat Siap & 40 & 64,5 \\
\hline Jumlah & 62 & 100 \\
\hline
\end{tabular}

Tabel 1. tentang hasil pre test kesiapsiagaan siswa dalam menghadapi bencana gempa bumi pada siswa SDN 86 Kota Bengkulu menunjukkan mayoritas responden penelitian dengan proporsi $64,5 \%$ sangat siap dalam menghadapi bencana gempa bumi kemudian responden dengan proporsi $8,1 \%$ belum siap dan $8,1 \%$ kurang siap dalam menghadapi bencana gempa bumi.

Tabel 2 Distribusi frekuensi Post Test Simulasi Penanggulangan Bencana gempa Bumi Terhadap Kesiapsiagaan Siswa SDN 86 Kota Bengkulu

\begin{tabular}{ccc}
\hline $\begin{array}{c}\text { Kategori } \\
\text { Kesiapan }\end{array}$ & Frekuensi & Persentase \\
\hline Belum Siap & 1 & 1,6 \\
\hline Kurang Siap & 2 & 3,2 \\
\hline Hampir Siap & 4 & 6,5 \\
\hline Siap & 2 & 3,2 \\
\hline Sangat Siap & 53 & 85,5 \\
\hline Jumlah & 62 & 100 \\
\hline
\end{tabular}

Tabel 2 tentang hasil post test kesiapsiagaan siswa dalam menghadapi bencana gempa bumi pada siswa SDN 86 Kota Bengkulu menunjukkan mayoritas responden penelitian dengan proporsi $85,5 \%$ sangat siap dalam menghadapi bencana gempa bumi kemudian responden dengan proporsi $1,6 \%$ belum siap dalam menghadapi bencana gempa bumi.

Tabel 3. Analisis Pengaruh Simulasi Penanggulangan Terhadap Kesiapsiagaan Siswa Dalam Menghadapi Bencana Gempa Bumi Pada Siswa SDN 86 Kota Bengkulu

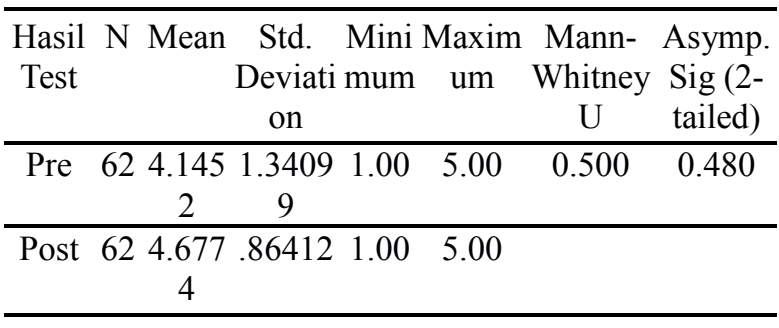

Hasil analisis pada tabel 3 menunjukkan bahwa adanya pengaruh simulasi penanggulangan terhadap kesiapsiagan Siswa dalam menghadapi bencana gempa bumi pada siswa SDN 86 Kota Bengkulu dengan nilai $p$ $=0,500$.

\section{PEMBAHASAN}

Hasil yang didapatkan pada pre test simulasi penanggulangan bencana gempa bumi terhadap kesiapsiagaan siswa di SDN 86 Kota Bengkulu menunjukkan $8,1 \%$ belum siap menghadapi bencana gempa bumi erat kaitannya dengan pengetahuan tentang penanggulangan bencana gempa bumi, simulasi, sosialisasi melalui media dan pengalaman yang kurang. Hal ini sesuai dengan penelitian terdahulu terkait Chairummi (2013), kesiapsiagaan pengurangan resiko bencana sangat diperlukan khususnya dalam menghadapi bencana gempa bumi yang disebabkan masih rendahnya pengetahuan anak-anak sekolah dasar yang merupakan resiko paling rentan terhadap terjadinya korban saat terjadi bencana. Herdwiyanti (2012) menjelaskan bahwa anak usia sekolah memiliki kemampuan dan sumberdaya yang terbatas untuk mengontrol atau mempersiapkan diri ketika merasa takut sehingga sangat bergantung pada pihak - pihak di luar dirinya supaya dapat pulih kembali dari bencana. Kerentanan anak - anak terhadap bencana dipicu oleh faktor keterbatasan pemahaman tentang resiko - resiko disekeliling mereka, yang mengakibatkan tidak adanya kesiapsiagaan dalam menghadapi bencana.

Menurut konsorsium Pendidikan Bencana (2011) menjelaskan bahwa gempa bumi pada 12 Mei 2008 di Sichuan China memberikan gambaran bahwa ketika bencana 
terjadi di jam sekolah memberikan dampak besar yang menewaskan sedikitnya 5.335 murid. Kesiapsiagaan merupakan kegiatan yang digunakan untuk mengantisipasi bencana. Faktor utama yang menjadi kunci untuk kesiapsiagaan adalah pengetahuan. Dengan pengetahuan yang dimiliki dapat mempengaruhi sikap dan kepedulian untuk siap siaga dalam mengantisipasi bencana. Kesiapsiagaan merupakan salah satu proses manajemen bencana, pentingnya kesiapsiagaan merupakan salah satu elemen penting dari kegiatan pencegahan pengurangan resiko bencana (Firmansyah, 2014).

Simulasi yang dilakukan dapat mempengaruhi pengetahuan, tindakan siswa terhadap penanggulangan bencana gempa bumi Simulasi merupakan cara penyajian pengalaman belajar dengan menggunakan situasi tiruan untuk memahami tentang konsep, prinsip atau ketrampilan tertentu. Simulasi dapat digunakan sebagai metode mengajar dengan asumsi tidak semua proses pembelajaran dapat dilakukan secara langsung pada obyek yang sebenarnya (Sanjaya, 2013). Pada penelitian ini simulasi yang digunakan adalah role playing atau bermain peran yaitu metode pembelajaran sebagai bagian dari simulasi yang diarahkan untuk mengkreasi peristiwa-peristiwa. Hal ini sesuai dengan Ramli Daud, dkk (2014) menerangkan bahwa pelatihan siaga bencana perlu dikembangkan mulai tingkat pendidikan dasar untuk membangun budaya keselamatan dan ketahanan khususnya untuk anak-anak dan generasi muda. Belajar dari pengalaman tentang banyak-nya kejadian bencana alam dan berbagai bahaya yang terjadi di Indonesia, maka pelatihan tersebut sangat diperlukan yang mencakup tentang cara yang tepat untuk menyelamatkan diri saat bencana terjadi dan juga cara menghindari kecelakaan yang seharusnya tidak perlu terjadi dalam kehidupan sehari-hari.

Hasil penelitian menunjukkan adaanya pengaruh simulasi penanggulangan bencana gempa bumi terhadap pengetahuan di SD N 86 Kota Bengkulu. Keberhasilan pelaksanaan simulasi tersebut karena mendapatkan dukungan dari berbagai pihak seperti guru yang mendampingi anak-anak selama simulasi, kemudian anak-anak sangat antusias mengikuti simulasi sampai selesai dan aktif memberikan feedback saat trainer memberikan pertanyaan, selain itu wali/orang tua siswa mendukung anak-anak dengan memberikan ijin untuk mengikuti simulasi, guru-guru juga memfasilitasi terhadap pelaksanaan pelatihan seperti terlibat dalam memberikan informasi tentang pelatihan kepada siswa dan orang tua siswa. Hal ini sesuai dengan Filina (2013) bahwa metode role playing suatu bentuk permainan anakanak yang aman dan bentuk-bentuk permainan yang sesuai dengan struktur lingkungan atau permainan-permainan dengan menggunakan boneka, rumahrumahan, yang pada dasarnya mendramatisasikan tingkah laku dalam hubungannya dengan masalah sosial.

Dengan dramatisasi anak berkesempatan melakukan, menafsirkan dan memerankan suatu peranan tertentu. Melalui kegiatan ini siswa akan aktif membicarakan masalah-masalah yang ditemuinya, kemudian menginformasikan hasil pengalaman melalui kegiatan berbicara. Pernyataan tersebut juga didukung oleh Siska (2010) terhadap penerapan metode role playing pada anakanak usia dini juga menunjukkan terdapat peningkatan ketrampilan sosial dan ketrampilan berbicara pada anak-anak usia dini. Keterlibatan dan kemampuan anak dalsam melakukan simulasi siaga bencana menunjukkan semua anak aktif dalam melakukan setiap tindakan simulasi setelah dilakukan 5 kali. Tindakan simulasi terdiri dari 6 tindakan yang dilakukan di dalam ruangan dan di luar ruangan.

Upaya yang dapat dilakukan dalam meningkatnya kesiapsiagaan siswa didukung oleh peran guru dan orang tua. Sekolah siaga bencana merupakan rencana tindak lanjut untuk menjadikan SD N 86 Kota Bengkulu sebagai SD siaga bencana. Beberapa materi yang diajarkan dan kegiatan yang dilakukan antara lain: lokakarya pengurangan resiko 
bencana;

pengenalan dan pembuatan peta evakuasi; pelatihan tanggap darurat; pengembangan sekolah yang aman; simulasi; Pelatihan pengintegrasian pengurangan risiko bencana ke kurikulum sekolah. Simulasi /pelatihan ini diharapkan berkelanjutan setiap 3-6 bulan sekali.

\section{KESIMPULAN}

Simulasi dan pemberian edukasi terhadap guru dan orang tua siswa dilakukan memberikan pengaruh terhadap kesiapsiagaan Siswa SDN 86 Kota Bengkulu. Simulasi yang dilakukan dapat berpengaruh terhadap tindakan yang dilakukan saat bencana gempa bumi terjadi.

\section{SARAN}

Diharapkan kepada masyarakat, khsusunya para siswa dapat memahami teknis dalam menghadapi Bencana Gempa Bumi.

\section{DAFTAR PUSTAKA}

Afandi R. 2014. Pengaruh Pelatihan Simulasi Terhadap Pengetahuan Siswa Kelas X IPS Tentang Mitigasi Bencana Gempa Bumi di SMA Muhammadiyah 1 Surakarta, Fakultas Keguruan dan Ilmu Pendidikan. Universitas Muhammadiyah Surakarta

Ajzen, I. (1991). "Theory of Planned Behavior". In Organizational Behavior and Human Decision Processes, 50, 179-211. From http://people .umass.edu/aizen. (Diunduh pada 20 September 2018).

Ajzen, I. (2005). Attitudes, Personality and Behavior, (2nd edition),Berkshire, UK: Open University Press-McGraw Hill Education.

Bakornas PB. 2007. Pengenalan Karakteristik Bencana dan Upaya Mitigasinya di Indonesia.Jakarta:Badan Nasional Penanggulangan Bencana.

BAPPENAS., 2006. Rencana Aksi
Penanggulangan Gempa bumi 2006 di Provinsi Jawa Tengah dan Daerah Istimewa Yogyakarta, Jakarta.

Badan Rehabilitasi dan Rekonstruksi (BRR). 2009. Rekonstruksi Aceh-Nias Dilanjutkan Pemprov", Detik com, 17 April Diakses 2 September, 2014.

BNPB., 2012. Pedoman Penyelenggaraan Latihan Kesiapsiagaan Penanggulangan Bencana: Jakarta.

Departemen Kesehatan R.I. 1993. Buku Pedoman Pengukuran Keberhasilan Pelatihan, Jakarta.

Departemen Kesehatan R.I. 2009. Pedoman Penanggulangan Bencana Bidang Kesehatan, www.ppk-depkes.org

Fika Nur Indriasari, Pengaruh Pemberian Metode Simulasi Siaga Bencana Gempa Bumi Terhadap Kesiapsiagaan Anak Di Yogyakarta. Jurnal Keperawatan Soedirman (The Soedirman Journal of Nursing), Volume 11, No.3 November 2016)

Filina.(2013). Efektifitas Metode Role playing Untuk meningkatkan Kosakata Anak tunarungu. Jurnal Ilmu Pendidikan khusus, 1(1)

Hely. 2013. Pengaruh Pengetahuan dan Pelatihan Kesiapsiagaan Penanggulangan Bencana Gempa Bumi Terhadap Kesiapsiagaan Tenaga Kesehatan Di RSU Bunda Thamrin Kota Medan, Fakultas Kesehatan Masyarakat, Universitas Sumatera Utara

Konsorsium Pendidikan Bencana., 2011. Kerangka Kerja Sekolah Siaga Bencana, Jakarta

LIPI-UNESCO/ISDR., 2006. Kajian Kesiapsiagaan Masyarakat Dalam Mengantisipasi Bencana Gempa Bumi dan Tsunami, Deputi Ilmu Pengetahuan Kebumian Lembaga Ilmu Pengetahuan Indonesia, Jakarta.

Ramli Daud, Sri AdelliaSari, Sri Milfayetty, M. Dirhamsyah. 2014. Jurnal Ilmu Kebencanaan (JIKA) ISSN 2355-3324 volume 1 nomor 1 Pages pp. 26- 34. Pascasarjana Universitas Syiah Kuala. 
Sofyatiningrum. E. 2009. Modul Ajar Pengintegrasian Pengurangan Risiko Gempa Bumi, Pusat Kurikulum Badan Penelitian dan Pengembangan Kementerian Pendidikan Nasional, Jakarta.

Twigg J. 2007. Karakteristik Masyarakat Tahan Bencana, DFID Disaster Risk Reduction Interagency Coordination Group Whaley's

Steward, D \& Wan, T.T.(2007). The Role of Simulation and Modeling in Disaster Management. JMed Syst. 3, 125-130.

UNCRD. (2009). Mengurangi Kerentanan Anak-anak Sekolah terhadap Bahaya Gempa Bumi. Proyek Inisiatif Keselamatan Sekolah Terhadap Gempa Bumi (SESI). UNCRD 